Research Article

\title{
Perineal Body Length and Pelvic Organ Prolapse in Menopausal Women
}

\author{
Panjang Perineal Body dan Prolaps Organ Panggul pada Perempuan Menopause
}

\author{
Chairun Nisa, David Lotisna, Deviana S. Riu, St. Maisuri T. Chalid \\ Department of Obstetrics and Gynecology \\ Faculty of Medicine Universitas Hasanuddin \\ Dr. Wahidin Sudirohusodo General Hospital \\ Makassar
}

\begin{abstract}
Objective : To determine the correlation between the perineal body length and the Pelvic Organ Prolapse (POP) in menopausal women.

Methods : The Total Vaginal Length (TVL), Genital Hiatus $(\mathrm{GH})$, and Perineal Body (PB) length as the POP-Q component were measured at 60 menopausal women enrolled in a cross-sectional study.

Results : Menopausal women with POP have the shorter perineal body $(63.3 \%$; $<3 \mathrm{~cm})$ compared with menopausal women without POP $(36.7 \%$; $\geq 3 \mathrm{~cm})$. The mean length of the perineal body in menopausal women who suffer POP 2.81 $\pm 0.26 \mathrm{~cm}$ while in women without POP is $3.23 \pm 0.17 \mathrm{~cm}$. POP risk was 25 times in menopausal women with a perineal body length $<3 \mathrm{~cm}$ compared with longer perineal body ( $p$ $=0.01 ; \mathrm{OR}=25.4 ; 95 \%$ CI 3.1-209.1).
\end{abstract}

Conclusions : Perineal body length is a risk factor for pelvic organ prolapse in menopausal women.

Keywords : perineal body, prolapse, pelvic organ prolapsed.

\begin{abstract}
Abstrak
Tujuan : Menentukan korelasi panjang perineal body dengan kejadian Prolaps Organ Panggul (POP) pada perempuan menopause.
\end{abstract}

Metode : Pengukuran komponen POP-Q meliputi total Vaginal Length (TVL), Genital Hiatus $(G H)$, dan panjang perineal Body (PB) dilakukan pada 60 perempuan menopause yang dilibatkan dalam penelitian potong lintang.

Hasil : Perempuan menopause dengan POP memiliki perineal body yang lebih pendek $(63,3 \% ;<3 \mathrm{~cm})$ dibandingkan dengan perempuan menopause tanpa POP (36,7\%; $\geq 3$ $\mathrm{cm})$. Panjang rata-rata perineal body pada perempuan menopasue yang menderita POP 2,81 $\pm 0,26 \mathrm{~cm}$ sedangkan pada perempuan tanpa $P O P$ adalah $3,23 \pm 0,17 \mathrm{~cm}$. Risiko POP 25 kali pada perempuan menopause dengan panjang perineal body $<3 \mathrm{~cm}$ dibandingkan dengan tubuh perineum yang lebih panjang ( $p=0,01 ; O R=25,4 ; 95 \%$ CI 3,1-209,1).

Kesimpulan : Panjang perineal body merupakan faktor risiko prolaps organ panggul pada perempuan menopause.

Kata kunci : perineal body, prolapsed, prolaps organ panggul.

Correspondence author: Chairun Nisa.chairun_nisa_sunusi@yahoo.com

\section{INTRODUCTION}

The weakness of the pelvic floor support structure causes urogenital prolapse. Approximately 50\% of parous women will develop prolapse and 10$20 \%$ of them with serious symptoms. Prolapse is associated with decreased quality of life and as a cause of pelvic organ dysfunction. Incidence of prolapse increases with age ${ }^{1}$. Approximately $50 \%$ of women over 50 years have urogenital prolapse complaints. ${ }^{2}$ The etiology of prolapse of pelvic organs is multifactorial, based on epidemiological studies there was evidence that pelvic organ prolapse is associated with parity, particularly multiplying and complicated vaginal delivery. ${ }^{3}$
Pelvic Organ Prolapse Quantification (POP-Q) has been recognized as a worldwide measurement standard. ${ }^{4}$ POP-Q component measurements are easy, sensitive and specific to anatomical changes. ${ }^{5}$ Perineal body (PB) is measured from the posterior boundary of the genital hiatus (HG) to the midpoint of the anal canal. ${ }^{3}$ This study aims to determine the correlation between the perineal body length and the Pelvic Organ Prolapse (POP) in menopausal women.

\section{METHODS}

The Health Research Ethics Committee of Medicine Faculty Universitas Hasanuddin, 
Makassar approved the study. A cross-sectional study conducted at Wahidin Sudirohusodo Hospital and affiliated hospitals at the Department of Obstetrics and Gynecology at Universitas Hasanuddin from December 2017 to February 2018. The Total Vaginal Length (TVL), Genital Hiatus $(\mathrm{GH})$, and Perineal Body (PB) length as the POP-Q component were measured at menopausal women. Data were analyzed with Chi-square test, and $p$-value $<.05$ was considered statistically significant.

\section{RESULTS}

Table 1 shows most menopausal women with pelvic organ prolapse aged $\geq 60$ years $(88.3 \%$ ) with $80 \%$ had BMI less than $30 \mathrm{~kg} / \mathrm{m} 2$ and only ten women using hormonal contraception. The study also showed that women with pelvic organ prolapse, all of which had a parity of $>3$ compared with 15 women without prolapse. Other characteristics are shorter than $60 \%$ in women aged $>60$ years compared with $60 \%$ in women aged $<60$ years. Women aged $>60$ years have a shorter perineal body $(p=0.001)$. Women with PB length $<3 \mathrm{~cm}$ has had more children $(>3)$ compared with longer PB length. POP risk was 25 times in menopausal women with a perineal body length $<3 \mathrm{~cm}$ compared with longer perineal body ( $p=0.01 ;$ OR $=25.4 ; 95 \%$ CI 3.1-209.1).

Table 1. Patients Characteristics

\begin{tabular}{|c|c|c|c|c|c|c|c|c|c|c|c|c|c|c|}
\hline \multirow{2}{*}{ Characteristics } & \multicolumn{2}{|c|}{ Prolapse } & \multicolumn{2}{|c|}{ Normal } & \multirow{2}{*}{ P-value } & \multirow{2}{*}{ OR } & \multirow{2}{*}{$\begin{array}{c}95 \% \\
\text { CI }\end{array}$} & \multicolumn{2}{|c|}{ PB $<3 \mathrm{~cm}$} & \multicolumn{2}{|c|}{ PB $\geq 3 \mathrm{~cm}$} & \multirow{2}{*}{ P-value } & \multirow{2}{*}{ OR } & \multirow{2}{*}{ OR } \\
\hline & $\mathbf{n}$ & $\%$ & $\mathbf{n}$ & $\%$ & & & & $\mathbf{n}$ & $\%$ & $\mathbf{n}$ & $\%$ & & & \\
\hline \multicolumn{15}{|l|}{ Age (years) } \\
\hline$<60$ & 5 & 16.7 & 20 & 66.7 & 0.01 & 10 & 2.934 & 1 & 5.3 & 24 & 58.5 & 0.01 & 25.4 & 3.1209 .1 \\
\hline$\geq 60$ & 25 & 83.3 & 10 & 33.3 & & & & 18 & 94.7 & 17 & 41.5 & & & \\
\hline Parity & & & & & & & - & & & & & & & \\
\hline$<3$ & 0 & 0 & 15 & 50.0 & 0.01 & - & & 0 & 0 & 15 & 36.6 & 0.001 & - & - \\
\hline$\geq 3$ & 30 & 100 & 15 & 50.0 & & & & 19 & 100 & 26 & 53.4 & & & \\
\hline \multicolumn{15}{|c|}{ Body mass index $(\mathrm{kg} / \mathrm{m} 2)$} \\
\hline$<30$ & 25 & 83.3 & 28 & 93.3 & 0.42 & 2.8 & 0.515 .7 & 15 & 78.9 & 38 & 92.7 & 0.193 & 3.4 & $0.7-16.9$ \\
\hline $\begin{array}{l}\geq 30 \\
\text { Using contrace }\end{array}$ & 5 & 16.7 & 2 & 6.7 & & & & 4 & 21.1 & 3 & 7.3 & & & \\
\hline No & 20 & 66.7 & 23 & 76.7 & 0.57 & 0.61 & $0.2-1.9$ & 16 & 84.2 & 27 & 65.9 & 0.246 & 2.7 & $0.7-11.1$ \\
\hline Yes & 10 & 33.3 & 7 & 23.3 & & & & 3 & 15.8 & 14 & 34.1 & & & \\
\hline
\end{tabular}

Table 2. Perineal Body (PB) Length in Prolapse and Normal Menopausal Women

\begin{tabular}{lccccc}
\hline \multirow{2}{*}{ PB length $(\mathbf{c m})$} & \multicolumn{2}{c}{ Prolapse } & \multicolumn{2}{c}{ Normal } & \multirow{2}{*}{$\boldsymbol{P}$-value } \\
\cline { 2 - 5 } & $\mathbf{n}$ & $\%$ & $\mathbf{n}$ & $\%$ & \\
\hline$<3$ & 19 & 63.3 & 0 & 0.0 & $<0.01$ \\
$\geq 3$ & 11 & 36.7 & 30 & 100.0 & \\
PB length (mean \pm SD cm) & $2.81 \pm 0.26$ & $3.23 \pm 0.17$ & $<0.01$ \\
\hline
\end{tabular}

Our study found that postmenopausal women with more pelvic organ prolapse had perineal body length $<3 \mathrm{~cm}$ (63.3\%) compared with menopausal women who did not have pelvic organ prolapse had $r$ perineal body $>3 \mathrm{~cm}$. The mean length of the perineal body in menopausal women who suffer POP $2.81 \pm 0.26 \mathrm{~cm}$ while in women without POP is $3.23 \pm 0.17 \mathrm{~cm}$ (table2).

\section{DISCUSSION}

Menopause generally occurs at the age of 4555 years while the mean age for Indonesian women having menopause at age 50 years. Pelvic organ prolapse found that pelvic organ prolapse increased $16-20 \%$ every ten years of age increase. Increased age is also associated with the loss of elastin that leads to the weakness of tissue due to the effects of gravity straightening back the collagen fibres. Although collagen fibres are strengthened up to $400 \%$ with the increase of age, the total strength of urogenital tissue decreases by approximately $60 \%{ }^{6}$ A study show that most of the women seeking for pelvic floor disorders were 60 years and older. ${ }^{7}$

Parity is also a factor that affects the prolapse of pelvic organs in our study. A study found more 
than $90 \%$ of pelvic organ prolapse patients are multiparous. ${ }^{8}$ Previous study show compared with nulliparous women; multiparous women had the higher risk for prolapse (4-fold vs 8.4fold risk of prolapse. ${ }^{9}$ In addition, the higher risk for prolapse (11-fold) for multiparous compared with nulliparous women. ${ }^{10}$ Asian women with high parity have an increased risk of prolapse of the anterior vaginal compartment as European women. ${ }^{11}$

Our study also showed body mass index $<30 \mathrm{~kg} / \mathrm{m} 2$ not as a risk factor of POP in menopausal women. Other studies have shown that overweight and obesity are significantly associated with prolapse in all compartments ${ }^{12}$ while suggests that increased BMI is a risk factor for urinary incontinence and alvi but not a risk factor for pelvic organ prolapse. ${ }^{13}$

Another finding of our study is PB length $<3 \mathrm{~cm}$ mostly observed in menopausal women aged $>60$ years, whereas $P B$ length $>3 \mathrm{~cm}$ observed in women aged $<60$ years. A study shows perineal body $<3 \mathrm{~cm}$ found in older women compared with younger women with perineal body $\geq 3$ $\mathrm{cm} .{ }^{14}$ In younger women, collagen 'S' forms easily stretched. In older women, there is increased intercellular and intramolecular collagen crosslinking, causing the 'S' form to become more rigid so that the perineal body tissue may shrink. ${ }^{6}$ A previous study found no difference in weight and height between women with a perineal body length $<3 \mathrm{~cm}$ and $\geq 3 \mathrm{~cm}$. ${ }^{15}$ Similar results were also found that the length of the female perineum was not associated with other anthropometric measurements although height was known to be associated with female pelvic size. ${ }^{16}$ However, another study found menopausal women who had pelvic organ prolapse had longer PB length $(>3 \mathrm{~cm})$ in white and black women aged 35-64 years with length of PB was $3.94 \mathrm{~cm}$

\section{CONCLUSION}

Perineal body length is a risk factor for pelvic organ prolapse in menopausal women.

\section{REFERENCES}

1. Swift, SE. Epidemiology of pelvic organ prolapse; in: Ostergard's Urogynecology and Pelvic Floor Dysfunction. 5th edition. Lippincott Williams and Wilkins: Philadelphia. 2003:35-41.

2. Balmfort, J Robinson, D. Pelvic Ogan Prolapse; In Evidence-Based Physical Therapy for Pelvic Floor. Elsevier: Philadelphia. 2007:235-6.

3. Mouritsen L. Classification and evaluation of prolapse. Best Pract Res Clin Obstet Gynecol. 2005;19(6):895911.

4. Bump, RC, Cundiff, GW. Pelvic Organ Prolapse in Clinical Urogynaecology. 2nd edition. Churchill Livingstone: Philadelphia. 2000:357-70.

5. Pearce M, Swift S, Goodnight W. Pelvic Organ Prolapse: Is there a difference in POPQ exam results based on time of day, morning or afternoon? Am J Obstet Gynecol. 2008;199(2):200.e1-5.

6. Petros, PEP. The female pelvic floor: function, dysfunction and management according to the integral theory. 2nd edition. Springer: Berlin. 2004: 14-5.

7. Luber KM, Boero S, Choe JY. The demographics of pelvic floor disorders: current observations and future projections. Am J Obstet Gynecol 2001;184:1496-501.

8. Dunivan GC, Lyons $K E$, Jeppson PC, Ninivaggio CS, Komesu YM, et al. Pelvic Organ Prolapse Stage and the Relationship to Genital Hiatus and Perineal Body Measurements. Female Pelvic Med Recons Sur. 2016;22(6):497-500.

9. Patel $D A, X u X$, Thomason AD, Ransom SB, Ivy JS, DeLancey JO. Childbirth and pelvic floor dysfunction: An epidemiologic approach to the assessment of prevention opportunities at delivery. Am J Obstet Gynecol. 2006;195(1):23-8.

10. Siddighi, S. Surgical management of anterior vaginal wall prolapse. In: Siddighi S, Hardesty JS, eds. Urogynecology \& Female Pelvic Reconstructive Surgery: Just the Facts. New York, NY: McGraw-Hill; 2006:121-8.

11. Duong $\mathrm{TH}, \mathrm{Korn} \mathrm{A}$. Predictors of advanced pelvic organ prolapse in Asian women. J Reprod Med. 2009;54(8):48892.

12. Hendrix SL, Clark A, Nygaard I. Pelvic organ prolapse in the Women's Health Initiative: gravity and gravidity. Am J Obstet Gynecol. 2002;186:1160.

13. Chen CC, Gatmaitan P, Koepp S, Barber MD, Chand B, et al. Obesity is associated with increased prevalence and severity of pelvic floor disorders in women considering bariatric surgery. Sur Obes Relat Dis. 2009;5(4):411-5.

14. Geller EJ, Robinson BL, Matthews CA, Celauro KP, Dunivan $G C$, et al. Perineal body length as a risk factor for ultrasound-diagnosed anal sphincter tear at first delivery. Int Urogynecol J. 2014;25(5):631-6.

15. Eid SM. Is Perineal Body Length Measurement Reinforcing the Decision About Performance. Or Avoidance of Episiotomy? AAMJ, 2011;9(3) Suppl.-2: 209-28.

16. Deering $\mathrm{SH}$, Carlson $\mathrm{N}$, Stitely $\mathrm{M}$, Allaire $A D$, Satin $A J$. Perineal body length and lacerations at delivery. J Reprod Med. 2004;49(4):306-10. 